Metka Kostanjevec

PRVA Gimnazija Maribor

metka.kostanjevec@prva-gimnazija.org

\title{
Distance Education During the Covid-10 Epidemic as a Challenge and Opportunity for the Personal and Professional Development of a School Librarian
}

\begin{abstract}
Due to the COVID-19 epidemic, all schools had to close their doors last year. Classes moved to a virtual environment, and students and teachers were left without the opportunity to visit school libraries overnight. Therefore, the school library of the Prva gimnazija Maribor has operated smoothly throughout the time of the epidemic and strives to facilitate the work of students, teachers, and other employees as much as possible, continue to promote reading, develop reading and information literacy, and at the same time enrich the educational process. The article presents how we found our way to our readers despite the difficult situation.
\end{abstract}

Keywords: school library, school librarian, distance education, COVID-19 epidemic, Prva gimnazija Maribor

\section{A challenge for everyone}

The year 2020 posed a special challenge to the whole world. The COVID-19 epidemic stopped the flow of time almost overnight and moved our lives almost entirely to the shelter of our homes. Schools and school libraries also had to lock their doors, while distance education has become our daily routine. However, the suspensions and restrictions have not stopped our work and efforts to operate continuously. School librarians and teachers are all too aware of the importance of supporting all people, especially children and young people, in learning and promoting reading anytime, anywhere, if we want them to become better people, to be able to look critically at the world, think with their own minds, and became responsible and demanding citizens. Therefore, the school library of the Prva gimnazija Maribor has operated smoothly throughout the time of the epidemic and strives to facilitate the work of students, teachers, and other employees as much as possible, continue to promote reading, develop reading and information literacy, and at the same time enrich the educational process. The employees of the school library have grasped the time of the epidemic as an opportunity to deepen our knowledge, further educate and train ourselves in the knowledge and mastery of new digital media, and thus 
further contribute to the excellent functioning of the library in the future. During the epidemic, the need to recognise the changing role of the school library in modern society, to introduce high-quality services for students and teachers in the digital age, and to reconsider the role of the school library in the process of literacy, learning, and reading was again expressed. The role and importance of the school library and the school librarian in the educational process is remarkable and irreplaceable. We will present to the participants how we confront this special time of distance education in the school library of the Prva gimnazija Maribor during the COVID-19 epidemic, what we offered to our users so that they could do their job as easily and smoothly as possible, and stay in mental and physical good shape. It is also important to consider what will happen when schools and school libraries are open again. Going back to school will certainly not be easy for all students. Also, their absence from the school environment will undoubtedly have greatly reduced children's learning efficiency. At that time, school librarians will certainly play an important role again. School libraries are the space in a school that, in an almost miraculous way, has been proven to help students relax and "open up", to tell their peers and the school librarian about their worries, doubts, and problems. All of this has certainly accumulated greatly among many young people during the epidemic.

\section{The role of the school library}

"School libraries exist throughout the world as learning environments that provide space (physical and digital), access to resources, and access to activities and services to encourage and support student, teacher, and community learning. /.../ A school library is a school's physical and digital learning space where reading, inquiry, research, thinking, imagination, and creativity are central to students' information-to-knowledge journey and to their personal, social, and cultural growth." (IFLA, 2015, p. 16)

"The school library program and its qualified school library professionals focus on student growth by providing equitable access for learning experiences, resources, and learning spaces that enable all members of the school community to become engaged critical thinkers, effective readers, and responsible users, evaluators, and creators of information in multiple formats." (IFLA, 2021, p. 1)

In Slovenia, school libraries are an integral part of the public service in the field of education. They carry out library activity as a component of the educational process for various types of educational institutions.

The basic task of every school library is the systematic collection, processing, storage, presentation, and putting into use the material that students and teachers need in their work. It 
must also take care of educating its users, especially in developing information literacy, and promoting reading.

All of this sets out the fundamental tasks of a good school librarian: to teach, manage, lead, collaborate, and engage in the wider community (Steinbuch, M. et al., 2010; Kurikul ..., 2008; IFLA, 2019).

The school library is essentially a physical space. However, during the school lockdown which happened because of the COVID-19 epidemic, it shifted and expanded its premises into the virtual environment. The COVID-19 pandemic caused a very rapid, intense, almost dramatic transformation in the functioning of the educational process and, consequently, in the operation of school libraries.

"Education was transformed from a traditional classroom practice to a remote digitized one." (Iivari, Sharma, Ventä-Olkoonen, 2020, p. 4)

Suddenly, an entire generation of children and young people, as well as teachers and others involved in the educational process, even parents, had to start working with different digital tools. That was not easy at all "even if digitalization in education has been a hot topic already for ages within different disciplines and digital tools are extensively already utilized in schools." (Iivari, Sharma, Ventä-Olkoonen, 2020, p. 4)

As Corbett and Brown said (2015), the primary challenge for libraries and distance librarians was "to provide library services and resources that equal those that are available on campus for the traditional student."

With school closures, many students and teachers lost access to the place they found comfort in and full of knowledge - the school library — but resourceful school librarians did not give up. We found alternative innovative ways to work in the new unknown conditions that had no precedent. We moved teaching to the virtual environment, we tried to find and offer our users as many open and free online sources of information as possible, we organised so-called office hours remotely, advising users by phone or email on how and where to find the material they needed to work, and we have moved a variety of reading promotion activities online.

Below, I present how the staff of the school library of the Prva gimnazija Maribor confronted this special time of distance education during the COVID-19 epidemic, what we offer our users so that they could do their job as easily and smoothly as possible and stay in good spirits, in mental and physical shape.

\section{The digitized everyday life of Prva gimnazija Maribor school library during school lockdown}


Prva gimnazija Maribor is a state general upper-secondary school (i.e. grammar school) for 15to 19 -year-old students. Its tradition goes back to 1850 . We strive to encourage our students to acquire broad knowledge, boost their creativity and critical skills, and to develop relations based on the principle of humanity, mutual respect and responsibility. Our motto is Per aspera ad astra (Through hardships through the stars). (https://www.prva-gimnazija.si/en)

The school library of the Prva gimnazija Maribor is really the heart of our school. In "normal" times, when education takes place in school, the school library is always full of students. They come here to study, to do homework, and to offer each other help with various classes. The school library is their refuge when they have free time or are waiting to go home. In the reading room of the school library or in a quiet room, they prepare for tests and exams in peace. On the couch, the school librarian co-teaches with other teachers, and students can read newspapers and magazines undisturbed, talk, and even play chess.

Our school library often becomes a place for teaching other topics, not only pedagogical activities, which are in the domain of the school librarian. In this case, the school librarian works in concert with teaching colleagues to provide the optimum learning experiences for students. Each member of the teaching team contributes their different areas of expertise to the design and implementation of teaching and learning activities.

In any case, our school library is always lively, so my first concern when the school had to close was how to keep in touch with users remotely so that they would still be regular visitors when they returned to school. At that time, I found it especially important and, at the same time, an exceptional opportunity to once again remind the entire school community of the importance of the existence, operation, and continuous development of the school library, without which there is no good education. Therefore, my first decision, made together with the school management, was that the school library would not close its doors to its users during the epidemic, but would merely adapt to the given situation and continue to strive to carry out its primary mission. Thus, our school library has functioned smoothly throughout the epidemic and offered support to students, teachers, and other employees as well as parents who needed help with working from home or when helping their children with school tasks.

To make it work, we planned and carried out the following activities:

1) "Stay in touch": At the beginning of the school lockdown in spring 2020, I emailed all students and staff on several occasions informing them that school library services would be available to them no matter what. If they needed any materials, they just needed to call or email. The material was then handed over to users in various ways: those who live in Maribor received the material at school (by contactless collection), those from other municipalities had the books 
either personally delivered to their homes or sent by regular mail (the borders between municipalities were closed).

2) Lists of web addresses and links to useful e-content (e. g. published works of literature, dictionaries, encyclopedias, museum and gallery collections, etc.) were published on the school library website and regularly updated.

3) Cooperation with teachers: The use of learning technology in schools was not systematic before the pandemic. Distance learning increased the use of tablets, computers, and all sorts of digital tools. The Google online classroom, ZOOM, and Microsoft Teams became our everyday reality. But not all the teachers were familiar with the different types of online environments, and many did not have very good digital skills. In order to make work easier for all of them, we set up the so-called Technical Assistance Group at the school, which included IT teachers, information and communication technology staff, and a school librarian. Once a week, all the teachers met at ZOOM meetings, where we exchanged experiences in groups using different e-tools and technologies and helped each other acquire the necessary new knowledge for the effective use of technology. We also planned interdisciplinary lessons to provide the optimum learning experiences for students.

4) Cooperation with publishers: free access to textbooks, workbooks, and other digital materials was obtained to facilitate distance learning.

5) Cooperation with the public library: Mariborska knjižnica has so much to offer. We have been collaborating with them for many years and have encouraged students to register and become a member. Students are exempt from membership fees. Maribor Public Library consists of 20 library branches (in the city and also in suburbs and in the countryside where our students come from), and a Mobile Library (Bibliobus) with 47 stops. The membership card is valid in all of its branches. Their online resources are excellent; therefore, during school lockdown, students could access e-materials that they needed for school work.

6) Teaching 'library information skills': One of the basic tasks of every school library is to teach our users how to use the library, digital literacy etc. "I think the best response of a capable educator is someone who focuses on student learning no matter what." (Ellis, 2020) In the form of independent or cross-curricular lessons for all students, I conducted lessons on the safe use of the Internet, how to assess the quality of websites, on searching for material in COBISS (COBISS $=$ Cooperative Online Bibliographic Information System and Services), citing sources and literature (APA standard), and searching for and using reference literature on the Internet. Distance learning was implemented using ZOOM and Google Classroom.

7) One of the most important things at my job for me is reading promotion. So, during lockdown, I tried really hard to help all our users. Even though they no longer had access to the 
books stored on bookshelves of the school library, I did everything to provide them with not just the materials they needed for learning and teaching but especially with the fiction they read for pleasure. In this time of digital transformation of everyday life, it really did not matter to me in what form any book was read - in printed or digital form. For me, the most important thing was to motivate my readers to keep reading.

To achieve this:

* I invited all students and staff to participate in the Prva gimnazija Maribor Reading Badge. At the online events in April 2020 and 2021, we announced the award winners and rewarded all participants with a book, a personalised bookmark, and chocolate. The response was overwhelming.

* We regularly publish the list of new books in the school library on our website.

* The Teachers' Reading Club has been active for fifteen years. We meet once a month in the school reading room to discuss the books we read. We choose the titles democratically - every time someone suggests a title and then we decide together what we will read next time. During the distance learning period, we moved our monthly meetings to the virtual environment.

* "Growing Up with a Book" (https://www.jakrs.si/bralna-kultura/rastem-s-knjigo): It is a national project for the promotion of reading culture. Its purpose is to motivate students of the last three years of primary school and secondary school to read young adult literature by Slovenian authors and to encourage them to visit general public libraries. The project was first carried out by the Ministry of Culture in the school year 2006/2007, initially only in primary schools. When it was founded in 2009, the Slovenian Book Agency took over the management of the project. Growing Up with a Book is carried out in cooperation with general public libraries, Slovenian primary and secondary schools, primary schools with an adapted programme, educational establishments for children and young people with special needs and primary and secondary bilingual schools in neighbouring countries (Austria, Hungary, Italy). We also cooperate with teachers of Slovenian at so-called Saturday schools (America, Australia), at supplementary Slovenian classes abroad (Belgium, BiH, Serbia, Croatia, France, etc.) and at European schools (Brussels, Luxemburg, Frankfurt, etc.).

All students received their copy of the selected book on a visit to their nearest general public library organised for this occasion and which is part of the curriculum. In addition to receiving the book the visit also informs students about library and information science, the latest in Slovenian young adult literature and the selected book and its author. During the school year meetings of students and the authors of the selected books also take place in several schools across Slovenia, in the neighbouring countries and elsewhere around the world, and presentation video-materials are produced. 
Last year, the implementation of the project was slightly delayed, and direct visits to public libraries were not possible. The action has moved into the online environment here as well. Students were addressed by librarians from the general library in a virtual environment.

* National Common Reading Month \& EUReads (https://nmsb.pismen.si/): Successful campaigns or reading initiatives are a practice in various European countries and also in Slovenia, many institutions in the field of reading culture and the development of reading literacy are already for decades we have been preparing various activities for children and youth, for families, for everyone generation. The project National Common Reading Month was first implemented in 2018. It lasts from September 8 (International Literacy Day) until the end of Children's Week in the second week of October. The long-term goal is to raise the reading culture and literacy of all inhabitants in Slovenia and abroad. During distance learning, we moved this month to the ZOOM virtual environment. We conducted several literary meetings at a distance, to which we invited everyone who is in any way connected with our school - students, teachers and their families. In 2019, as part of the National Common Reading Month project, we joined the European reading campaign EURead for the first time, which connects existing reading activities across Europe with the aim of raising awareness of the importance of education and literacy in early childhood. The common goal of the campaign is to give every citizen the opportunity to become a reader and to participate fully in European society.

- International School Library Month: thematic group readings were held three times a week in the "school reading room", where we read books on the mysteries of the mountains, famous Slovenians, outstanding Slovenian women ...

In honour of General Rudolf Maister (the square where our school is located is named after him), we read his poetry during Slovenian lessons in all classes.

\section{* Reading Mountains Festival}

(https://www.alpconv.org/en/home/projects/reading-mountains-festival/): The festival was moved to the virtual environment last year. Participants read excerpts from "mountain" travelogues, poetry, biographies of mountaineers, proverbs and wisdom about the mountains, and shared memories of the wonderful moments we have experienced as hikers among the peaks. * I organised remote literary evenings (e. g. on World Poetry Day, World Book Day, various commemorative events, etc.);

* To observe World Children's Book Day, I read the fairy tale "The Secret of the Empty Frame" by Bina Štampa Žmavc, recorded myself, uploaded the recording to the school website, and invited all first graders to listen;

* Students' presentations of books they read: As I also teach Slovenian, the students got one of the grades by giving a 10-minute presentation about a book they had read. I had compiled a 
list of 60 recommended books for them. I deliberately chose books that are not on the school (compulsory) reading list; I drew on my own reading experience, I used the Guidelines for Quality Juvenile Fiction and reviews in Bukla magazine, which regularly presents new books from Slovenian and foreign markets. In class, I briefly introduced and showed each of the books to students to make it easier for them to choose the one they were going to read. The result was impressive - the students presented what they had read in a truly experiential and well-reasoned way. For the vast majority, reading was a pleasure. They circulated the books so that they ended up reading more than one.

* "A Book Fair": In February this year, learning moved back to the classroom. To celebrate International Book Day, I displayed nearly 3000 books, either written off during the inventory of the school library shelves or generously donated by Slovenian publishers, on the benches and windowsills of the school and, after an announcement on the school radio, invited all students and staff to take what they liked. After a week, there were only 72 books left.

\section{After the epidemic}

Now that the epidemic is slowly subsiding, the future needs to be considered. What have we learned from the distance learning experience? "The epidemic proved to be a nice opportunity to accelerate the processes of digitization of the learning process, to modernize the school system and make it more innovative." (Turk Niskač, 2020) I think one of the most obvious insights is that at least basic knowledge of the use of new technologies is essential these days. Most students are undoubtedly more adept at knowing and mastering various digital applications and tools than teachers. Today's generation of young people has different expectations of education and the school library than previous generations. As Groeling and Boyd (2009) found out, "students today are confronted by a tremendous amount of information in which they can easily become lost, and they rely heavily upon search engines for their information needs in order to navigate and manage the information glut they face". Therefore, in my opinion, one of the most important tasks of the school librarian of the future will be obtaining, managing, and promoting the efficient and responsible use of different types of digital resources.

Going back to school certainly wasn't easy for all students and teachers. For all employees in education, it will surely be a great challenge to deal with the consequences of the epidemic on the behaviour of us and our colleagues, students, and their parents. Especially "for children and adolescents with mental health needs, such closures mean a lack of access to the resources they usually have through schools. /.../ School routines are important coping mechanisms for young people with mental health issues. When schools are closed, they lose an anchor in life and their symptoms could relapse.” (Lee, 2020, p. 421) 
"The consequences will first have to be identified, then addressed appropriately and those affected will be helped to deal with them." (Dobnik Renko et al., 2020, p. 2)

I am convinced that in this process school librarians will again play an important role. School libraries are the space in a school that, in an almost miraculous way, has been proven to help students relax and "open up", to tell their peers and the school librarian about their worries, doubts, and problems. One possible method we can use to help our users is bibliotherapy. Merga (2020) said that "students can deal with issues challenging their well-being from a safe distance when they are experienced by book characters."

Furthermore, keep in mind that reading for pleasure is strongly associated with mental well-being. It is therefore essential that we continue to encourage and promote leisure reading in a variety of ways. One of the best ways is to set an example ourselves.

\section{Conclusion}

What I've presented is distance schooling from my own perspective and experience. I have to admit that it was stressful at the beginning, but we adapted very quickly and did our best to maintain contact between the library, the books, the students, and other users. If nothing else, I believe that I have managed to demonstrate time and again my sincere enjoyment in what I do and my passion for reading and everything to do with books. Convincing young people that reading is worth all the time and effort is an ongoing battle. This challenging year has given us much valuable experience we can apply in the live classroom teaching in the future. I also know that much more can be done, and I look forward to the challenges of the future-either face to face or remotely.

\section{References}

American Association of School Librarians. Transforming learning. (2020). School Librarian Role in Pandemic Learning Conditions. (2020, July 13). Retrieved February 10, 2021, from http://www.ala.org/aasl/sites/ala.org.aasl/files/content/advocacy/SchoolLibrarianR olePandemic_Resources_Chart_200713.pdf

Corbett, A., \& Brown, A. (n. d.). The Roles that Librarians and Libraries Play in Distance Education Settings. Online Journal of Distance Learning Administration, Vol. XVIII, No. 2, (Spring 2015). Retrieved February 09, 2021, from https://www.westga.edu/ distance/ojdla/summer182/corbett_brown182.html 
Dobnik Renko, B., Janjušević, P., Kreft Hausmeister, I., Lampret, M., Mikuž, A., Mlinarič, A., Pristovnik, T. (2020). Duševno zdravje otrok in mladostnikov v času epidemije covida-19: gradivo za vzgojno-izobraževalne ustanove v času postopnega odpiranja vrtcev in šol. Ljubljana: Zbornica kliničnih psihologov Slovenije, Sekcija za otroško in mladostniško klinično psihologijo. Retrieved February 09, 2021, from http://klinicna-psihologija.si/wp-content/uploads/2020/05/ZKP_Dusevno_zdravje _otrok.pdf

Ellis, L. (2020). Pandemic Preparedness for School Libraries. Knowledge Quest (March 27). Retrieved February 10, 2021, from https://knowledgequest.aasl.org/pandemic-preparedness-for-school-libraries Groeling, J., \& Boyd, K. A. (2009). The Impact of Distance Education on Libraries. Theological Librarianship: An Online Journal of the American Theological Library Association, Vol. 2, No. 1 (June 2009). Retrieved February 09, 2021, from

https://www.researchgate.net/publication/26626374_The_Impact_of_Distance_Ed ucation_on_Libraries

IFLA. (2020). COVID-19 and the Global Library Field. Key Resources for Libraries in responding to the Coronavirus Pandemic. (Last update: 13 October 2020).

IFLA. (2015). School Library Guidelines. 2nd revised edition. Retrieved January 13, 2021, from

https://www.ifla.org/files/assets/school-libraries-resource-centers/publications/ifla -school-library-guidelines.pdf

IFLA. (2020). Library Re-Opening Strategies Around the World. Retrieved September 13,2020 , from https://www.ifla.org/files/assets/hq/topics/libraries-development/documents/overv iew_of_re-opening_plans_6_june.pdf

IFLA - smernice za šolske knjižnice. (2019). 2nd ed. Ljubljana: Zveza bibliotekarskih društev Slovenije Retrieved December 03, 2020, from https://www.ifla.org/files/assets/school-libraries-resource-centers/publications/ifla -school-library-guidelines-sl.pdf

IFLA/UNESCO. Manifest o šolskih knjižnicah. (2006, August 1). Retrieved December 03, 2020, from https://archive.ifla.org/VII/s11/pubs/mani-sl.pdf 
IFLA School Library Manifesto (2021). Retrieved May 12, 2021, from

https://www.ifla.org/files/assets/school-libraries-resource-centers/publications/ ifla $\% 20$ school_\%20manifesto_2021.pdf

Iivari, N., Sharma, S., Ventä-Olkoonen. (2020). Digital transformation of everyday life How COVID-19 pandemic transformed the basic education of the young generation and why information management research should care? International Journal of Information Management, 55 (2020) 102183. Retrieved March 07, 20210, from https://reader.elsevier.com/reader/sd/pii/S0268401220310264?token=7BA93495B42 0F6C5145CD0872809AE9F4A0EBDC83EA64CEAE548ED182F107D03A086732 A2CE1A32ED6427D1E225760F0\&originRegion=eu-west-1\&originCreation=20210 512112535

KURIKUL: knjižnično informacijsko znanje: gimnazija: splošna, klasična, strokovna gimnazija. Purkat, N. (Ed.). (2008). Ljubljana: Ministrstvo za šolstvo in šport: Zavod RS za šolstvo. Retrieved December 03, 2020, from

http://eportal.mss.edus.si/msswww/programi2013/programi/media/pdf/ucni_nacrti/K _KNJIZN_INF_ZNANJE_gimn.pdf

Lee, J. (2020). Mental health effects of school closures during COVID-19. The Lancet Child \& Adolescent Health, Vol. 4 (2020, June). Retrieved February 09, 2021, from https://www.thelancet.com/action/showPdf?pii=S2352-4642\%2820\%2930109-7

Merga, M. K. (2020). A place to get away from it all: 5 ways school libraries support student well-being. The Conversation. (2020, September 29). Retrieved February 09, 2021, from

https://theconversation.com/a-place-to-get-away-from-it-all-5-ways-school-librari es-support-student-well-being-145180

Pravilnik o pogojih za izvajanje knjižnične dejavnosti kot javne službe. Uradni list $R S$, 73/03, 70/08 in 80/12. (2003, July 29). Retrieved December 03, 2020, from http://www.pisrs.si/Pis.web/pregledPredpisa?id=PRAV5163

Steinbuch, M., Novljan, S., Zabukovec, V., Andrin, D., Brilej, I., Fekonja, R., . . Zwitter, S. (2010). Posodobitve pouka v gimnazijski praksi: knjižnično informacijsko znanje. Ljubljana: Zavod RS za šolstvo. Retrieved December 03, 2020, from https://www.zrss.si/projektiess/gradiva/posgim/GRA_Knjiznicno_informacijsko_zna nje.pdf

Turk Niskač, B. (2020). "Koronazmagovalci znanja": pouk na daljavo in nove oblike discipliniranja. Alternator: misliti znanost, 45 (2020, October 1). Retrieved 
December 04, 2020, from

https://www.alternator.science/sl/daljse/koronazmagovalci-znanja-pouk-na-daljav o-in-nove-oblike-discipliniranja/

Zakon o knjižničarstvu (ZKnj-1). Uradni list RS, 87/01, 96/02 - ZUJIK in 92/15. (2001, November 8). Retrieved December 03, 2020, from

http://www.pisrs.si/Pis.web/pregledPredpisa?id= ZAKO2442

Zakon o spremembah in dopolnitvah Zakona o knjižničarstvu (ZKnj-1A). Uradni list RS, 92/2015, 10396. (2015, December 4). Retrieved December 03, 2020, from https://www.uradni-list.si/glasilo-uradni-list-rs/vsebina/2015-01-3612?sop=2015-013612 